\title{
The Impact of Family Income on Students Financial Attitude
}

Doc. Ph. D. Dorjana NANO

Lecturer University "Eqrem Cabej”

Email: nano.dori@yahoo.com

Ph. D. Teuta LLUKANI

Lecturer University "Eqrem Cabej"

Email: t. llukani@gmail.com

Ph. D. Antoneta Polo

Lecturer University "Eqrem Cabej"

Email: neta_polo@gmail.com

Abstract

This research explores the differences on Financial Attitudes among Albanian university students based on their family income. The main objectives of this study are: i) firstly, to assess students attitude towards money management practices; ii) to examine whether their financial attitude differs based on the level of family income; and iii) finally, to present some conclusions and recommendations for parents, practitioners and students in way that they can shape healthy financial habits. An instrument comprised of specific and personal questions is administered to 637 students from five public and two private universities in Albania. The consistency and reliability of the survey is tested by the dimension reduction technique and Cronbach Alpha test. Data analysis is conducted based on analyse of variance. The results exhibits that Albanian university students do not have good financial attitude. Parental income is found to influence their children attitude towards money issues. Students with low parental income are discovered to show better financial attitude in comparison with other categories. This research recommends parents and other practitioners to teach proactively students about money smart.

Keywords: financial attitude, family income, Albanian university students.

\section{Introduction}

In recent years there has been a growing concern about student's attitude toward money management. University students make up one segment of the population that especially need to be aware of the impact of their financial decisions. Inadequate attitude toward the importance of budgeting or tracking expenses can lead in misusing money and building bad financial behavior ( $i$. e. plentiful spending on goods and services for the purpose of impressing others) among young adults. The financial decisions made early in life create habits difficult to break which affect students' ability to become financially secure adults (Martin \& Oliva, 2001). A large body of literature researches student's attitude toward personal finances and continually reports that students are risked of unreasonable financial attitude and behavior. Dilworth, Chenoweth and Engelbrecht (2000), conducted a research to explore students and their parents' attitude toward everyday finances. They identified seven major themes: necessities, security, luxuries, savings, debts, charity, and money philosophy. Students' participants were found to anticipate major purchases as homes, cars, and new furnishings. Authors suggested that financial education should play a more role to help students nearing graduation to temper their aspiration for luxurious and to learn patience in accomplishing financial goals. In another study conducted to 401 undergraduate students from a midsized northwestern university, Coleman explicated that almost half of the participants felt that they knew "more than most". As expected, non-business majors, were unlikely to admit that they knew "more than most" in comparison with business ones. Other studies conducted in the early 2000s (Leila and Laily, 2011; Richter and Prawitz), continued to find that students are not much confident about money matters. Danes (1994) suggested the need for parents to realize when children are 
ready to be involved in various financial decisions so they can take advantages of these windows of opportunity by creating adequate financial attitude and learning experience. Hayhoe et al. discovered that if parents used money as a reward, students are more likely to borrow money. According to Jewkes (2009, the majority of children create money habits - good or bad - at home. Furthermore, studies have discovered that students who report high parental income are more prone to spending money, less interested in financial matters and see less need for precautionary saving. Parental income can be used as an indicator of a student's lifestyle, social class, and the resources and opportunities that are available to them (Robb and Pinto, 2010). These results lead to the following questions: Does students' parental income have an influence on their financial attitude? Does higher family income result in not appropriate financial attitude? The main aim of this paper is to explore whether there is any discrepancy in students' financial attitude based on their family income. The main objectives of this study are:

- $\quad$ Firstly, to estimate the level of students' financial attitude based on different classes of family income;

- Secondly, to investigate whether students' financial attitude is influenced by their family income;

- Finally, to draw some conclusions and recommendations in order to help students establish reasonable financial attitude.

This research raises the following hypothesis:

\section{Students' family income influences their financial attitude.}

\section{Methodology}

This study utilizes a questionnaire designed in two parts covering personal and financial attitude questions. The personal section requires information about: gender, age, parental income, work experience, money management source of learning, etc. The financial attitude includes one question on how safe does the student feel about money management and eleven attitude statements to capture their attitudes toward money practices. A five point Likert scale is utilized in order to measure on how the participants agree or disagree with the particular financial attitude statements. Participants are asked to select from 1 , if they completely disagree with statement given to 5 whether they completely agree. The average response for the twelve statements provides an overall score for the students' financial attitude. 637 participants from five public and two private universities across Albania participated in the study. Public universities involved in this research are: University of Tirana; Agriculture University of Tirana; University "Aleksandër Moisiu”, Durrës; University "Aleksandër Xhuvani", Elbasan and University "Eqrem Çabej", Gjirokastër. Private universities considered are: University "Marlin Barleti", Tiranë and "Kristal" University, branch Përmet. The response rate counts for 95\% (607 of 637). Questionnaires completed less than $95 \%$ of the questions involved are considered unavailable. Data are processed in the Statistical Package for the Social Sciences (SPSS 20). The consistency and validity of the survey are tested based on the factor analyses and the reliability analysis. In addition, the one way Welch ANOVA technique is utilized for investigating the differences in financial attitude based on students' family income. Furthermore, multiple comparisons between different groups, classified according family income classes, are examined by considering Tukey post-hoc test.

\section{Data Analyzing and Findings}

\section{- $\quad$ The Reliability of the questionnaire}

The internal consistency of the questionnaire is tested based on the value of factor loading provided by the factor analyses of each component included in the financial attitude section. The reliability of the survey is measured based on the Cronbach's Alpha index yielded by the reliability analysis. The high proportion of variance in our variables tested by KaiserMeyer - Olkin's test (KMO = 0. 792) indicates a valuable factor analysis. The usefulness of factor analysis is also confirmed by the zero value (less than 0. 05) of the significance level of Bartlett's Test of Sphericity. Three out of thirteen components included in the factor analyses are extracted based on the Principal Component Analysis, since they loaded less than 0.4 (Table 1). The other factors loaded resulted greater then 0.4 , showing a good internal consistency of the survey. Meanwhile, the Cronbach's Alpha index stands at 0.704 considering all the items that are resulted successfully 
from the factor analyses. A reliability coefficient of 0.70 or higher is considered "acceptable" as recommended by Cavana et al. , (2001).

\section{Table 1: Factor \& Reliability Analysis}

\begin{tabular}{|c|c|c|}
\hline & Factor Loading & \multirow[b]{3}{*}{$\mathrm{KMO}=0.792$} \\
\hline Maintaining financial records & .467 & \\
\hline Spending less than your income is very important & 579 & \\
\hline I believe I have in control my financial situation & 614 & \multirow{8}{*}{$\begin{array}{l}\text { Bartlett's Test of Sphericity } \\
\text { Sig. } 000\end{array}$} \\
\hline I feel capable to manage optimally my future income. & 619 & \\
\hline I am certain about my money spending. & 507 & \\
\hline I feel credit cards are safe and risk free & 296 & \\
\hline I believe is very important to save money each month. & 492 & \\
\hline I feel life insurance is an important way to protect loved ones. & 585 & \\
\hline $\begin{array}{l}\text { I feel is very important to read and understand the contract of an } \\
\text { apartment lease or a loan before I sign. }\end{array}$ & .612 & \\
\hline I like talking with my friends/colleges about money management issue. & 491 & \\
\hline & & $\begin{array}{l}\text { Cronbach's Alpha index: } 0 . \\
704\end{array}$ \\
\hline
\end{tabular}

\section{Sample Characteristics}

Table below illustrates information about the participants' characteristics. Based on the statistics provided in table 2, it can be seen that the majority of the respondents were males $(71 \%)$, aged $18-22$ years old. Almost half of the respondents (48. $1 \%$ ) have reported middle or lower middle family income (greater than 20,000 Lekë - 60, 000 Lekë). $36.6 \%$ reported upper middle or high family income (greater than $60,000-80,000$ Lekë, or greater than 80,000 Lekë), and only $10.6 \%$ displayed low parental income $(0-20,000$ Lekë). Most of the respondents considered school as their primary source of money management learning, and only a third reported their family. The majority $(61.6 \%)$ reported their university studies to be fully paid by their parents.

\section{Table 2: Sample Characteristics}

\begin{tabular}{|l|l|l|}
\hline Gender & Frequency & Percentage \\
\hline Female & 176 & $29 \%$ \\
\hline Male & 431 & $71 \%$ \\
\hline Total & 607 & $100 \%$ \\
\hline Years of Age & & \\
\hline $18-22$ & 439 & $72.3 \%$ \\
\hline $23-29$ & 126 & $20.8 \%$ \\
\hline $30-39$ & 37 & $6.1 \%$ \\
\hline 39 and over & 4 & $0.7 \%$ \\
\hline Missing system & 1 & $0.1 \%$ \\
\hline Total & 606 & $99.9 \%$ \\
\hline Family Income & & \\
\hline $0-20,000$ Lekë & 64 & $10.6 \%$ \\
\hline Greater than 20, 000-40, 000 Lekë & 152 & $25.0 \%$ \\
\hline Greater than 40, 000-60, 000 Lekë & 140 & $23.1 \%$ \\
\hline Greater than 60, 000-80, 000 Lekë & 121 & $19.9 \%$ \\
\hline Greater than 80, 000 Lekë & 106 & $16.8 \%$ \\
\hline Missing system & 24 & $4.6 \%$ \\
\hline Total & 607 & $100 \%$ \\
\hline Primary Source of Money management learning & & \\
\hline
\end{tabular}




\begin{tabular}{|l|l|l|}
\hline My family & 176 & $29.0 \%$ \\
\hline School & 239 & $39.4 \%$ \\
\hline Discussion with friends & 21 & $3.5 \%$ \\
\hline Media & 33 & $5.4 \%$ \\
\hline Experience & 135 & $22.2 \%$ \\
\hline Total & 604 & $99.5 \%$ \\
\hline University education paid by: & & \\
\hline Self & 120 & $19.8 \%$ \\
\hline Parents & 374 & $61.6 \%$ \\
\hline Mostly self & 31 & $5.1 \%$ \\
\hline Mostly parents & 44 & $7.2 \%$ \\
\hline $50 \%$ self, 50\% parents & 29 & $4.8 \%$ \\
\hline Others & 5 & $0.8 \%$ \\
\hline Total & 603 & $99.3 \%$ \\
\hline
\end{tabular}

\section{- $\quad$ Students Financial Attitude}

In order to capture the level of financial attitude and its differences among students with different family income, an analysis of variance (ANOVA) and descriptive statistics are conducted. Table 3 below provides detailed information about the mean and standard deviation according to different groups' income. Statistics demonstrates that students scores around four at the financial attitude showing not a satisfactory performance, since the upper limit is 10 . The overall score of financial attitude is illustrated to be statistically significant among different groups $(F=3.069$, sig. $=0.016)$.

\section{Table 3: ANOVA}

\begin{tabular}{|c|c|c|c|}
\hline & Mean & Standard Deviation & \\
\hline $0-20,000$ Lekë & 4.07 & .582 & \multirow{5}{*}{$\begin{array}{l}F=3.069 \\
\text { Sig. } 0.016\end{array}$} \\
\hline Greater than $20,000-40,000$ Lekë & 3.95 & .596 & \\
\hline Greater than $40,000-60,000$ Lekë & 4.01 & 575 & \\
\hline Greater than $60,000-80,000$ Lekë & 4.03 & 415 & \\
\hline Greater than 80,000 Lekë & 3.95 & .663 & \\
\hline
\end{tabular}

In closer inspection of the data, it can be observed that students who have reported the lowest family income $(0-20,000$ Lekë) have yielded the highest score of financial attitude $(M=4.07)$, followed by students with middle or upper middle family income $(M=4.01, M=4.03)$. Students, who declared lower middle parental income and those with the highest ones, are shown to perform worse in financial attitude. This statistics support the hypothesis that students' parental income influences their financial attitude.

The Tukey Post Hoc test (table 4) provides evidence about the multiple comparisons of the financial attitude scores based on the variable family income. Results reveal a statistically significant discrepancy in financial attitude scores among students with lowest family income and those of lower middle family income. The mean difference between the lowest income students and the highest one is shown to be significant at $90 \%$ level of significant. This outcome approves the hypothesis that students' family income affects their financial attitude level. 


\section{Table 4: Tukey Post Hoc Test}

\begin{tabular}{|c|c|c|c|c|c|c|}
\hline \multirow[t]{2}{*}{ (I) Family Income } & \multirow[t]{2}{*}{ (J) Family Income } & \multirow{2}{*}{$\begin{array}{l}\text { Mean } \\
\text { Difference (I- } \\
\text { J) }\end{array}$} & \multirow[t]{2}{*}{ Std. Error } & \multirow[t]{2}{*}{ Sig. } & \multicolumn{2}{|c|}{ 95\% Confidence Interval } \\
\hline & & & & & $\begin{array}{l}\text { Lower } \\
\text { Bound }\end{array}$ & $\begin{array}{l}\text { Upper } \\
\text { Bound }\end{array}$ \\
\hline \multirow[t]{4}{*}{$0-20,000$ Leke } & Greater than $20,000-40,000$ Lekë & $.122^{*}$ & .044 & .042 & .00 & .24 \\
\hline & Greater than $40,000-60,000$ Lekë & .068 & .044 & .533 & -.05 & .19 \\
\hline & Greater than $60,000-80,000$ Lekë & .043 & .045 & .880 & -.08 & .17 \\
\hline & Greater than 80,000 Lekë & .124 & .047 & .064 & .00 & 25 \\
\hline \multirow{4}{*}{$\begin{array}{l}\text { Greater than } 20,000- \\
40,000 \text { Lekë }\end{array}$} & $0-20,000$ leke & $-.122^{*}$ & .044 & .042 & -.24 & .00 \\
\hline & Greater than $40,000-60,000$ Lekë & -.054 & .034 & .523 & -15 & .04 \\
\hline & Greater than $60,000-80,000$ Lekë & -.079 & .036 & .175 & -18 & .02 \\
\hline & Greater than 80,000 Lekë & .001 & .038 & 1.000 & -.10 & .10 \\
\hline \multirow{4}{*}{$\begin{array}{l}\text { Greater than } 40,000- \\
60,000 \text { Lekë }\end{array}$} & $0-20,000$ leke & -.068 & .044 & .533 & -.19 & .05 \\
\hline & Greater than 20,000 - 40, 000 Lekë & .054 & .034 & .523 & -.04 & .15 \\
\hline & Greater than $60,000-80,000$ Lekë & -.026 & .037 & .956 & -.13 & .07 \\
\hline & Greater than 80,000 Lekë & .055 & .038 & .601 & -.05 & 16 \\
\hline \multirow{4}{*}{$\begin{array}{l}\text { Greater than } 60,000- \\
80,000 \text { Lekë }\end{array}$} & $0-20,000$ leke & -.043 & .045 & .880 & -.17 & .08 \\
\hline & Greater than $20,000-40,000$ Lekë & .079 & .036 & .175 & -.02 & .18 \\
\hline & Greater than 40,000 - 60, 000 Lekë & .026 & .037 & .956 & -.07 & .13 \\
\hline & Greater than 80,000 Lekë & .081 & .040 & .245 & -.03 & .19 \\
\hline \multirow{4}{*}{$\begin{array}{l}\text { Greater than } 80,000 \\
\text { Lekë }\end{array}$} & $0-20,000$ leke & -.124 & .047 & .064 & -.25 & .00 \\
\hline & Greater than 20,000 - 40, 000 Lekë & -.001 & .038 & 1. 000 & -.10 & .10 \\
\hline & Greater than 40,000 - 60, 000 Lekë & -.055 & .038 & .601 & -.16 & .05 \\
\hline & Greater than $60,000-80,000$ Lekë & -.081 & .040 & .245 & -.19 & .03 \\
\hline
\end{tabular}

\section{Conclusions, Discussions and Recommendations}

This study exhibits the financial attitude of 607 students from multiple universities across the country. It reveals the level of financial attitude and its discrepancy among Albanian university students based on their family income. The study provides evidence that Albanian university students do not have a good attitude towards personal finance. One of the factors found to affect their attitude on personal finances is their parental income. Evidences suggest that students with low level of family income are more likely to have a better financial attitude in comparison with students with other parental income.

The outcomes of this research can be mainly explained by the inappropriate parental guidance about money management practices. Parents mostly neglect teaching children money matters everywhere. Students with higher parental income may have the attitude that money comes easily and they can buy whatever they want. The statistics of this study demonstrated that most of the students declared their university studies to be fully paid by their family. By not knowing the value of working for money and having almost financed their living and education spending, students are not fostered to prioritize, tracking expenses and following a monthly budget. On the other hand, students with low parental income may have being faced with difficulties early in life and have learn that money matters. 
Training parents on how to teach children healthy financial habits will make them capable to teach and model positive financial habits in the home. It is essential to parents to educate children to set priorities and give them a personal allowance in order to value money and their education. They can instruct their children for good or bad. Parents can teach their children that "money values", or "money is there to be spent". Finally, Proverbs 22:6 says: "Train up a child in the way he should go, and when he is old he will not depart from it. "Except the role of parents, institutions of higher education, banks and professionals could offer seminars to students on the importance and ways to establish a proactively financial lifestyle.

It is recommended that further quantitative research can be conducted in order to verify the other factors affecting students' financial attitude. In addition, future qualitative studies would be useful to gain insight in depth of students' financial attitude. Furthermore, other studies could be undertaken to understand the correlation between students' financial attitude and behavior. Finally, future researches can utilize the logistic regression method of study, in order to explicate students' financial attitude by considering other variables simultaneously.

\section{References}

[1] Atkinson, A. , F. Messy (2012): Measuring Financial Literacy: Results of the OECD / International Network on Financial Education (INFE) Pilot Study. OECD Working Papers on Finance, Insurance and Private Pensions, No. 15, OECD Publishing. http://dx. doi. org/10. 1787/5k9csfs90fr4-en.

[2] Cavana, R. Y. , Delahaye, B. L. \& Sekaran, U., (2001): Applied Business Research: Qualitative and Quantitative Methods. Queensland: John Wiley \& Sons Australia, Ltd.

[3] Coleman, S. , Financial Literacy and Attitudes Toward Personal Finance of College Undergraduates. http://rwahlers. iweb. bsu. edu/abd2008/papers/p08_coleman.

[4] Danes, S. M. (1994). Parental perceptions of children's financial socialization. Financial Counseling and Planning 5, $127-146$.

[5] Dilworth, J. L. , Chenoweth C, I. , Engelbrecht, J. , (2000). A Qualitative Study of the Money Goals of College Students and Their Parents. Journal of Association for Financial Counseling and Planning, 11 (2), 33-42.

[6] Hayhoe, C. R. , Leach, L. J. , Turner, P. R. , Bruin, M. J. , Lawrence, F. C. , (2000). Differences in Spending Habits and Credit Use of College Students. Journal of Consumer Affairs, 34 (1), 113-133.

[7] Jewkes D. Melanie, (2009): "Teaching Children Money Management". Finance \& Economics. University Cooperative Extension.

[8] Leila Falahati and Laily Hj. Paim, (2001). A comparative study in Money Attitude among University Students: A Gendered View. Journal of American Science, 7 (6).

[9] Martin, A. , \& Oliva, J. C. (2001). Teaching children about money: Applications of social learning and cognitive learning developmental theories. Journal of Family and Consumer Sciences, 93 (2), 26-29.

[10] Melanie D. Jewkes, (2009). Teaching Children Money Management. Finances and Economics.

[11] Richter, J. , Prawitz, D. A. , (2010): Attitudes of College Students Toward Credit Cards: A Comparison Of Credit Card User Types. Accessed online on June 2013 from http://www. mrupured. myweb. uga. edu/. . . Icredit_card_study_poster_abstract_EFERMA_2010_F1.pdf.

[12] Robb, C. A. \& Pinto, M. B. (2010): College Students and Credit Card Use: An Analyses of Financially at-risk students. College Students Journal, 44 (4), 823. 